\title{
THE OLD TESTAMENT AND THE NEW COVENANT
}

During my whole time of work as a teacher of the Old Testament there has been constant unrest concerning the theological status of the originally Jewish part of the Bible. There have been tendencies among clergymen of the previous generation to abolish the reading of the Hebrew Bible as compulsory for undergraduates. Like HarNack some learned men have proposed to supplant it by a study of the Septuagint ${ }^{1}$ ), not realizing the impossibility of a true scientific study of the Greek Bible without intimate knowledge of Hebrew. Such tendencies have in later years completely vanished. In Sweden e.g. the important work of the so-called "Uppsala-school" among other merits can claim the revival of the interest in Hebrew studies among the undergraduates. And in Denmark, in a plan for revision of the curriculum of the theological examinations this year the study of Hebrew by all lines of theological studies was taken for granted.

But of more importance than this has been the discussions of the theological signification of the Old Testament. The "critical" views, introduced in Denmark in the Eighties of the last century by BuHL, whose centenary can be celebrated on the 6th of September 1950"), and taught by his successor J. C. JACOBSEN in a way which made their acceptance by nearly all Danish clergymen from the years 1891 to his retirement in 1928 a necessity of conscience, had on the other hand made the Old Testament a book which more and more vanished from devotional reading of the younger generations. The strong opposition from the so-called "Inner-Mission" had had the effect of intimidating many young parsons and making them speak as little as possible of that part of the Bible. The New Testament was not taught in the same impressive way as the Old, wherefore the candidates did not feel the critical problems so compelling, so strongly appealing to their consciences, as in the case of the Old Testament.

*) Dit is vir die Redaksie in eer en genoeë dat die bekende Deense Outestamenticus van die Universiteit van Kopenhagen so aanstons bereid gevind is om in wetenskaplike bydrae van sy hand vir plasing af te staan: die opname beteken uiteraard nie dat die hier voorgedrae insigte die standpunt van die Redaksie weergee nie.

1) L. J. Kосн, Om Praesteudannelsen (1934).

2) On Burl's life and work, see the speech by Johs. Pedersex on the occasion of Buhl's death in 1932 in the Danish Academy, held in the meeting on he 3rd of March 1933. 
And in order to maintain peace of work in the parishes they in too many cases also maintained silence concerning the Old Testament. ${ }^{3}$ ) They "held their peace" in two significations of the phrase. And one understands them. On account of the vigorous propaganda of VILHELM BECK and his successors, down to the present chairman of the Inner Mission, Chr. Bartholdy, it has been no easy task to be a young parson in Denmark, coming from the theological teaching of the Copenhagen faculty with one's conscience tied to the noble and objective presentation of the arguments of JACOBSEN, with his strong personality appealing inexorably to one's Christian sense of truth and honesty, into a parish where the best and most deeply living Christians were the members of Inner Mission Community, all brought up in the "orthodox" view of the Bible as God's Word, literally understood, admitting no errors and no real contradictions in the texts. I understand very well that such young men did not touch upon matters which might lead to unfruitful and unpleasant encounters, but limited their Bible work to texts - above all the New Testament - on which there would be general agreement. It has been of great importance, and has done much damage to the life of the Danish Church, that the revivalist movements, to which the Church owes so much, tied themselves to the views of traditional "orthodoxy" from the beginning of the 19 th century, without yet giving a clear warning that the leaders, up to the present chairman of the Inner Mission, do not uphold the old views, but have accepted the new ones. The only, very unconspicuous, sign of the altered position was the recension of my studycircle-pamphlet Loven-Profeterne-Skrifterne from 1944, in the Weekly of the Inner Mission, where he used the cautious sentence that in several respects historical criticism was right and called the little book a happy attempt. ${ }^{1}$ )

It has during all my work on the Old Testament been my aim to find some acceptable solution of the problem, briefly stated in the

3) Of more outstanding works in the discussion of the critical views in Denmark I refer to BuHL's Til Vejledning $i$ de gammeltestamentlige Undersogelser (18951. P. Madsen, Tale ved Universitetets Reformationfest 1894 (,Fra Bethesda", no. 48, 10th Year; reprinted in: Om den gammeltestamentlige Kritik. En Forhandling mellem P. Madsen, J. H. Monrad, og V. J. Hoff (1895). Earlier: V. Obel, Om den gammeltestamentlige Kritik (1890). From later discussions I mention my own contributions: Det gamle Testamente, Tre Foredrag (1929), Loven-ProfeterneSkrifterne (1944). Dr. PAUL BRODERSE'N Introductory Essay to the first volume of Haandbog $i$ Kristendomskundskab 1941). J. C. JACOBSEN, Gammeltestamentlige Kritik $i$ Religionsundervisningen (1934) - against some views propounded with great vivacity, but not with strong foundations by dr. phil. Ernst Kaper. - On 1. C. JACOBSEN, see my obituary article in the Festskrift udg. af Kobenhauns Universitet $i$ Anledning af Universitetets Aarsfest 1949, and some supplementary pages in the "Stud. theol." - the periodical of the Copenhagen students, November 1948.

1) Indre Missions Tidende. April. 8th. 1945. 
superscription of this article. The leading thought in my work has been to find a solution which would satisfy both the modern scientific approach to the Bible and also the just claims of faith. Of course, I $\mathrm{am}$ aware that faith and criticism are different and in many respects seem to combat one another. But I have never been able to feel my sense of truth satisfied by "a double truth", a theory which had tc leave the scientific views of the present day out of the picture. The scientific view of the Bible and the History of Israel and the Early Church is not an eternally fixed quantity. It varies from age to age. New theories come to the fore and dominate the ideas of criticism. But the religious view cannot but start from these different theories. Therefore also theological thought on these matters are bound to vary from age to age, to some extent at least. A theory which makes a low bow to historical critism and acknowledges its right in the theological work, but then proceeds to use Biblical texts in a way which is quite contrary to the interpretation given to them by historical criticism of contemporary scholars, I have always refused to accept. It is therefore that I feel repelled by much of the work by BARTH and his pupils, inclusive my friend Wilhelm Vischer. ${ }^{1}$ ) The theological view of the Bible current in any age must always start from the actual situation in Biblical criticism and attempt to make the actual situation useful for the practical reading of the Bible.

This is, I admit, a claim which is not easily carried out. The theological views are generally formed by systematic theologians, who are not - on account of the increasing flow of literature which must be worked over to fulfil the task set before them - able to be quite up to date in their knowledge of the historical work on the Bible. Generally they mostly rely upon the material which was presented to them in their time as students, and they are accordingly very often about one generation behind the problems discussed by

1) The Biblical work of BARTH, as far as I can see, has been rightly characterized by Baumgartner, Die Auslegung des Alten Testaments im Streit der Gegenwart. Schweizerische Theologische Umschau, Juni/September 1941. pp. 19ff. cf. his criticism of Vischer's and HellaardT's work, ibid. pp. 24ff. My own recension of Vischer's first volume (Das Christuszeugnis des Alten Testaments I (1933) was published in Dansk Teologisk Tidsskrift 1938, pp. 65ff. Cf. also Eıchrodt in Theologie der Gegenwart 1935. pp. 125ff.; Theol. Blätter 1938; v. RAD, in Theol. Blätter 1935; El.LIGER, Zeitschrift für systematische Theologie 1937; HellaARd, in Theol. Blätter 1937. On the 2nd volume I refer to KuRT Galling's review in Deutches Plarrerblatt, 27 Dec. 1942. I think the result of the discussion around Vischer's work has been a positive appreciation of his INTENTIONS, but a nearly complete agreement that the intentions cannot be carried out in this manner. 
their contemporary colleagues in Biblicis. ${ }^{2}$ ) On the other hand, we historical theologians who as Christians wrestle with the theological problems involved in our actual work, are perhaps still more out of date as to systematic theology of our own day, and perhaps still more than our colleagues depend upon the dogmatics and religious philosophy taught by our teachers in our undergraduate days. But of course, such difficulties are only there to be conquered. And therefore I repeat the claim to any theologican trying to present a practical view of the Old Testament as expression of God's revelation in connection with Christianity, that he must establish a sound and true relation between the Bible as it is understood by sound scholarship of his own day and the theological and edificatory use he makes of it. If this claim is not fulfilled, the dogmatic or philosophical view which is propounded will necessarily be out of contact with problems for Christian use of the Bible raised by the Bible itself, when it is examined critically by historians.

As far as I see, the central question here must be the problem of the relations between the Testaments, viewed under the heading "Promise and Fulfilment". That is the view taken by the New Testament authors. And the modern approach to the Bible, on the basis of historical or so- called "Higher Criticism" has here changed the situation so radically that this problem must be of first importance to theologians and to the Church as a whole. I need not expound this matter lengthily. The "atomistic" quotations of the New Testament taken over from the method of the rabbis as also from Hellenistic Jewish learning, using Scripture sentences indiscriminately without any interest in context, neither literary nor historical, is so radically opposed to our way of reading, that there can be no question of asking people to use it to day. The use made of Hos. 11,1 in Matth. 2,15 is the example instar omnium.

The modern approach has of course felt the problem very early, and many, and many admirable, attempts have been made to give another and a fresh interpretation of the problem. I am not going here to review the history of his work. I think that the fundamental work was done by Joh. Chr. Konr. HofmanN, in his famous two volume book from 1841-44 Weissagung und E-füllung, in which he defends he thesis that not the words of the Old Testament, but the history of Israel constitutes the "foretelling" of Christ. The history of

3) This is in general also true e.g. of Hebert's interesting volumes The Throne of David, and The Authority of the Old Testament. 
Israel is a "prophetic history", fulfilled in the history of Christ and his Church. Christ is the central goal of history, not only of the history of Israel, but of all history. ${ }^{1}$ )

When in these pages I shall try and sketch a view of the relations between "The Old Testament and the New Covenant" - a formulation not coined by myself, but by the editors of a forthcoming book on Biblical problems by several different Danish theologians I shall not take up a discussion of the views of Bultmann briefly mentioned below. I think I may let his interesting descriptions stand, perhaps as a supplement to my own ideas. But in accord with the principle formulated above, I shall try a sketch of the relations between the two Covenants in connection with the ideas which I have set forth in my little book Messias - Moses redivivus - Menschen$\left.s s h n^{2}\right)$.

The "Prophetic" Line of History which underlies this book is based upon the view expressed by Mowinckel in his Psalmenstudien II (1922) and used by him to describe the origin of Jewish Eschatology. ${ }^{3}$ )

1) Cf. the famous, often quoted lines (1, pp. 15f.): ,Jeder Triumphzug, welcher durch die Strassen Roms ging, war eine Weissagung auf den Caesar Augustus denn was dieser immerzu war, das stellte der Triumphator an seinem Ehrentage vor: den Gott im Menschen, Jupiter im römischen Bürger. Darin dass Rom seinen Siegern diese Ehrenbezeugung zuerkannte, gab sich seine Zukunft zu erkennen, dass es die Welt durch den göttlich verehrten Imperator beherrschen würde" This is compared to the Passover Lamb as type of the Christ. Cf. the criticism by BultmanN in Studia Theologica II, I (1949:, pp. 27ff., where B. attempts to find the truth in the ideas of Hofmann. Bultmann examines the notions of the Covenant, the Kingdom of God, and of the People of God, and describes, on this examination, Old Testament History as Prophecy, fulfilled in the New Testament. The Fulfilment is expressed in the failure, the inner contradiction in the realization of the three notions in the history of Israel and Judaism. Cf. also the appreciation of HoFmanN given by $\mathrm{F}$. BuHL in his for his time, and in its introductory chapters still important De messianske Forjaettelser $i$ det Gamle Testament (1894), pp. 15f. Of important literature besides the just mentioned works I only refer to EICHRODT's Chapters in his Theologie des Alten Testaments.

2) Zwingli-Verlag, Zürich, 1948. My earlier treatments of similar questions in Finder vi Kristus $i$ det Gamle Testamente? (1938) (in the lines laid down by BuHL) and Loven - Profeterne - Skrifterne (1944) I also will regard as supplementary. not contradictory.

3) I regard Mowinckel's theory of the ancient Israelite Ascension Festival (Thronbesteigungsfest Jahwes) as right in all main points. The often repeated argunent, that we have no evidence of its existence in Israel I consider erroneous. The form-critical method of Gunkel which Mowinckil applies to the Psalms of Ascension, reconstructing their "place in life", their cultic function, from hints given by the poems themselves, is only a variation of the ancient philological way of reconstructing the historical background of a text by means of the hints found in the text itself; and it is wrong that we have no evidence of a festival of this kind: We have the well attested New Year Festival in the autumn; cf. my forthcoming article King ideology - Urmensch - Iroonbesteigungsfeest, in a coming fascicle cf the Studia Theologica. 
This view is briefly summarized in the heading of the last chapter of MowincKel's book: Vom Erlebnis zu Hoffnung.

Israel's religious history moves along this line. In the ancient festival of New Year - as well as in other festivals, e.g. above all the Passovercelebrations - the peoples of the Ancient East') "sacramentally") reiterated the fundamental, saving facts of their faiths. The central theme was that of the fight of the saviour-god, impersonated by the king, against the primeval chaos. The world was established firmly above the waters of the Flood, the king enthroned as guarantee of the Divine blessing for the coming year. But before this could be ensured the god had been obliged to descend into the depths of death, from where he however recovered and amid rejoicings of his people took his seat in his newly dedicated temple. The Ascension Psalms in the Old Testament show that these ideas to a great extent were assimilated by Israel, but modified, above all, "historified", i.e. attached to the history of Israel's deliverance from Egypt, which not only influences the Exodus-festival par excellence, Passover, but also the old Canaanite Winegathering festival, preserved in the Festival of Tabernacles, which in the period of the monarchy became the real New Year Festival, as it is to this day in Judaism. - The Israel of the Monarchy assembled at their sanctuaries to celebrate these facts, the creation of the world through Yahweh's victory over the chaos devils, historically understood as Rahab, Egypt, Pharao and his host. Israel's world stood again firmly on the waters of chaos, and God throned in the temple represented by the chosen

1) In addition to the work of MowiNCKEL I presuppose the description of Ancient Canaanite Festivals by HvidBerg in his examination of the ritual texts from Ugarit (Graad og Latter $i$ det Gamle Testamente (1938); Den israelitiske Religions Historie (1942), and also the development of the ideas of MowinCKEL given especially by ENGNELL and WIDENGREN, who above all-as also JoHs. PEDERSEN - have stressed the rôle of the king in the New Year celebrations as "saviour" and "mediator", fighting the chaos-powers and conquering them in the fight, which leads him near to defeat and to the gates of the underworld (descensus-psalms!), and in which he is rescued by Yahweh (the "resurrection" of the king). I do not give further literature, but only refer to the above-mentioned book Messias etc., and my review of Skandinavische Literatur in Theologische Rundschau 1949/49. supplemented by the just mentioned forthcoming article in Studia Theologica.

$\Rightarrow$ I use this word as a signification of the experience of the ancient "congregations", because it furnishes an illustration of what happens, when the fundamental history of salvation is enacted in the cultic drama, as understood by ViLHELM Gronhech in Essay on Ritual Drama in his The Culture of the Teutons I-II (1931): The history of salvation in Israel: the deliverance from Egypt is expersenced again by the offspring of those who first took part in the creation of the people. The cultic remembrance as a creative act is also described by JoHs. PEDERSEN in Israel III-IV. - It is my impression that these ideas are not easily understood by Netherlands and English scholars (outside the Anglican communion). Have Catholics and Lutherans, and especially Danes with the strong influence of Grundtvig's sacramental and Church-centred experience, in their "cultic attitude, a chance of understanding the actual reiteration of the saving facts in the cultic service? Are we ultimately perceiving a result of the old fatal contest between Luther and he Calvinistic forms of Christendom? 
king. God's son in whom $\mathrm{He}$ has pleasure, and the people through him receives the blessing of his "peace", wellbeing, fertility, victory over enemies, purification from sins. God and saviour-king are present, the people possesses in its midst the strength which will overcome Evil.

But in the course of time Israel's history teaches the people the lesson that this possession is unsafe. The catastrophes which during the history of the later monarchy weigh heavily on the minds of men, and at last the annihilation of political existence of an Israelite people, the exile and "the day of small things", bring it home to the people that Salvation is no possession, but a thing to come. The New Year Festival, the re-experience of the divine victory, becomes the eschatological Day of Yahweh. His Kingdom is not there now and here, in actual presence. It will come - and again and again Hope is kindled by revival of he expectation: Now it is near at hand! Israel has passed "from experience to hope".

The Church of the Messiah, founded by Jesus of Nazareth, believes that the kingdom came with him. In him the actual presence of God and Saviour is experienced in the sacrificial meal of the New Covenant, the new Passover Meal, the Holy Supper. But not only this. Also the eschatological aspect is there. He comes to the worshippers in the Service, but he is to come one day openly to accomplish the New Creation. In the experience of the Church assembled round the sacramental Christ, as in the picture by Raffael or in the altar piece by van Eyck in Ghent, a synthesis') of the experience of ancient Israel and the hope of Judaism is created.

I think it evident that already this statement of a religious historical development ${ }^{2}$ ) has pointed out to my readers how I propose to look at the relations between the Old Testament and the New Covenant.

The latter is not only, as Bultmann will, a fulfilment of the former on account of the breakdown ("das Scheitern") of the Old Covenant. The Old Covenant proved unsatisfactory. That is the truth of Bultmann's contentions. And this was felt already by men of the Old Covenant themselves. I only need to refer to the famous word on this matter, attributed to Jeremiah $(31,31 \mathrm{ff}$.) to illustrate this. ${ }^{3}$ ) It is a central expression of the transition from experience to Hegel.

1) Please don't charge me with Hegelianism! I have never read one line of

2) And please, don't charge me with evolutionism!

$\left.{ }^{3}\right)$ On this word, see the remarks of Rowley, The Authority of the Bible (1949), p. 8. 
hope in the religion of Israel. The Epistle to the Hebrews develops thoughts along similar lines. And, as just underlined, BultmanN's sagacious description of the contradictions inside the conceptions of the covenant and of the chosen people prove also the unsatisfactory character of the Old Testament.

This means that it can never be allowed to place the two Testaments on the same level. Our interpretation of the Old Testament must always start from its own words, and it is not legitimate interpretation to read into the words a "Christuszeugnis", which finds Christ speaking in them. Looking back from the Fulfilment we can discern pointers and types, prefiguring Christ and his Church. And the great thing about actual ideas of cultic experience and divine kingship is that the historical development to a great extent runs parallel to the theological interpretation of the prophetic history. ${ }^{1}$ ) This furnishes an important illustration to the principle laid down by HoFmanN. W a may say that it gives us a sounder basis for a renewal of some sort of typological interpretation. $\left.{ }^{2}\right)$ Criticism and Faith are nearer to one another than they have been for long.

But there is another line of thought which perhaps also may be of some importance. It differs from the point of view of Prophetic History introduced by HofmanN and adapted in the preceding pages. It starts, not from History, but from the $\mathrm{B}$ o o $\mathrm{k}$ itself, following the order of the Hebrew Canon, dividing the Old Testament into three parts, Law, Prophets, and Hagiographa. It starts from these collections as entire units and attempts to describe their religious p reachin $\mathrm{g}$, without entering upon the many questions of historical reality and the problems raised by parts of the writings which are of less edificatory value, or directly repelling to Christian view of God and life.

In the $\mathrm{L}$ aw the all-comprehending point of view is the goal to which it points: God choose this, in many respects coarse and sinful, nation for the sake of salvation for mankind. This goal is the main point of view. God has created the world to be prefect. But Sin spoiled his good work. During the primeval story the Yahwistic story-teller shows how God experimented to repair the damage: The radical purge: The Flood; the dispersion of the nations; and lastly: the election of Abraham to found a nation destined to bear blessing into the race which fell under God's curse through the sin of the first couple

1) This is my main point in the last chapter of my book Messias-Moses redivivus-Menschensohn.

2) On this see the article by C. M. Eusmax in the Lindblom-Festskrift (Svensk Exegetisk Aarsbok 1947). 
of men. The Call of Israel is to be the Saviour of the world. The st o r y told by the Yahwist preaches the Gospel of God's will to save the world condemned to death for its sins.

A means to this end is the strong element of $\mathrm{com} m$ a n d m e $\mathrm{nts}$ and rules imbedded in the tale of the Law, which has given the first third of the Old Testament its name. The Law. Much of this is admittedly mostly of interest for antiquarians. But besides that there are beginnings of a morality which is the sound base of every human community, God has here, as when he choose the coarse and sinful nation as means for the salvation of his creation, humbled himself and gone down into the human and much too human world for the sake of his great goal. The Law was brought in to educate Israel to its task to be the Saviour of the World. The inclination to forget this task reveals itself in the later strata of the Pentateuch, when this element of Law proprio sen s u dominates the historical material. Paul at last placed Law in its right position below the promise of salvation. ${ }^{1}$ )

The second part of Canon, the two fold section T he P r o phe t s, again taken as a whole exhibits the same comprehensive point of view as the Law, the goal of God, the Salvation of the world, and the subordinate, but definite position of the Law in this connection. The historical books, the prophetae priores, describe the Fall of Israel, as Genesis described the Call of Israel. But they also point to the saving factor, the Messianic Kingship. ${ }^{2}$ ) This sacral kingship has two functions, theologically speaking. It has the function in its own actual age to save Israel from its enemies. But it is, in addition to that, incipiently eschatological Messianic, pointing forward to its fulfilment in Jesus Christ, being an expression of God's presence in the world with all his powers of blessing, and thus a type of the work of Jesus Christ. The Old Testament however describes the Fall of Kingship. pointing to the deviation of the kings from God's Law, concretely expressed in the Deuteronomic claim of the centralisation of the cult. But this outward view is supplemented in the prophetae poste$r$ iores, in the prophecies of doom, where the Law is represented by the claims of social and moral justice.

1) cf. my articles Det israelitische historiesyn, Dansk Teologisk Tidsskrift 1944, and. Syndess sold er doeden, ibid., 1945.

2) Concerning the term Messianic, see Messias-Moses redivivus-Menschensohn, pp. 33ff. The criticism of SJOBERG, Suensk Exegetisk Aarsbok 1949, pp. 4of. in a very important article on the Prophets - is right: It may be dangerous to use the word Messianic of the early kingship without the eschatological connotation brought into it in the age of hope. But on the other hand, this new use of the word has the advantage that it can point to the link between the three stages in Israel $s$ religious history outlined above. For the sake of clarity we might use the terms "present Messiah" and "eschatological Messiah". 
But also the Gos p e 1 is represented in the Prophets, especially in the image of the Messianic Sacral King in his eschatological guise. The political picture in Is. 9 and 11, Micah 5 stresses, in actual opposition against the degenerated kingdom of the age of the prophets, the divine claims of justice and clemency. But in its purest form the Gospel is revealed in the poem on the Suffering Servant of Is. 53. This picture, on the other hand, has its clear limitations, in that it - under influence of the anti-Canaanite reaction - has eliminated all divine features and presents what could be called a description of Good Friday and Easter Morning deprived of the background in the Christmas Story.

And finally, the same points of view can be found in the $\mathrm{H}$ a $\mathrm{g}$ i o $\mathrm{graph}$ a. They are in different ways expressions of Law and Gos pel, but here more mingled in all the books than in the previous sections of the Canon. And here we meet the tendency to failure which BultmanN stresses - perhaps too one-sidely-in his article on Weissagung und Erfüllung. We see how the Wise try to realize the hope of Israel (the Gospel) through the Law, the mistake of the religion of Pharisaism. And Qohelet's unsolved doubts concerning God's justice is perhaps the most moving picture of the failure of the Old Testament. The failure of the Law is most vividly described by the Pharisee Paul. And so we have entered the fourth part of the Bible, which is originically linked to the Old Testament. The task set to Abraham and his race was not fulfilled. The Saviour of the World was not the Israelite nation, but the Messiah from Nazareth, who vicariously fulfilled the task of Israel and so - as the new Messianic King - founded the New Israel, the Church, the People of the New Covenant. ${ }^{1}$ )

Against the view of Hofmann that not the words of the Old Testament, but the history of Israel as a whole, are prophetic promises, BuHL $^{2}$ ) - acknowledging that Hofmann's view did not deny the prophetic contents of the words as explaining texts accompanying the pictures given by History - nevertheless found cause for criticism. BuHL finds that the prophetic word not always gets its proper weight. For Hofmann sometimes tries to restrict its contents, where the word in its free course transcends the contemporary stage of historical development, either in distinct wording, or at least through the wealth of intuitive vision which it contains. BuHL himself ${ }^{3}$ ) pointed out that the words of the prophets contain a distinction between a purely historical and a absolute eschatological element. They speak distinctly to their

1) This paraphraph of the article is a brief summary, somewhat revised, of my study-circle-book Loven-Profeterne-Skrifterne (1944).

2) De messianske Forjaettelser, pp. $15 \mathrm{f}$.

3) ibid., pp. $24 \mathrm{ff}$. 
own contemporaries about judgement and salvation, and these words are fulfilled, but not completely. He stresses that the prophets themselves attribute great importance to this relative fulfillment. The absolute eschatological element on the other hand is always proved false by history. The Messianic age and its preceding catastrophes never occurred. But this did not affect the prophets. They believed so firmly in the realization of Israel's hope and the final revelation of God's justice that no disappointment could shake their faith. Therefore this element passed on from one prophet to another, proving the power of hope to conquer time, and the later prophets are just as convinced of the near advent of salvation as were their predecessors. The advent of salvation was again and again postponed, but the preservation of such promises proves that the disappointment did not lead to the opinion that the prophecies were not true and of divine origin.

Many scholars, on the other hand, feel inclined to take this course concerning the absolute eschatological, never fulfilled element in prophecy. This element, loosened from its connection with contemporary history, seems to dissolve into pure abstractions which cannot be considered promises converning a more distant age. Already BuHL's predecessor in the 18th century, the disciple of Michaelis, Claus Frees HoRnemanN, in his commentary on Micha - the first historico-critical treatment of this prophetic book - had pointed out the absurdity in finding a connection between a Messiah fighting against Assyria and the Christ in the days of Pontius Pilate, who did not live under the circumstances alluded to by the prophet of the 8th century. In like manner SCHLEIERMACHER and his followers had found the abiding value of the prophetic preaching in its eternal fundamental thoughts, independent or all history, e.g. their idea of God, their conception of faith, their opposition to external cult etc., while their hopes and expectations centring round a coming glory and an ideal king must be considered beautiful dreams which for ever will have to wait for their fulfilment. On this background Christ and the Church will not stand as fulfilment of ancient oracles, but as the culmination of a religious evolution, begun by the Old Testament prophets and completed by the greatest prophet, Jesus from Nazareth. BuHL recognizes that also this view contains a certain amount of truth. Christ himself in claming to be the fulfilment of the ancient prophecies, nevertheless re-interprets them and lifts them into a higher sphere, where all the outwardly features clinging to the hopes of even the greatest prophets, vanish, so that not only the historical environments of the Messiah are others than in the original prophecy, but also the conception of the Messiah is changed so essentially. and so essentially purified, that it seems difficult to speak of a real fulfilment. But BuHL, on the other hand, maintains that this is not the whole truth. To find that truth he returns to the conception of Israel's 
history as containing types of later antitypes, leading up to the final fulfilment in the New Testament. He points out that this view is found inside the Old Testament itself, when earlier events, e.g. the deliverance from Egypt, are considered prefigurations of coming events (cf. Hos. 2,16; Is. 11,15-- etc.). And the expectation that the ancient events will come true in history in later days is not only a longing back to the Golden Age. But the prophets consider the coming events, prefigured in earlier history, far greater than the past, which is only the shadow of the coming reality. As example of this BuHL takes even the word, attributed to Jeremiah, the theme of our work (Jer. 31,31ff.). The Covenant founded by Moses is a prefiguration of the coming Covenant, but the latter, in greater perfection, brings what the former only gave in an imperfect expression $(31,33)$. And this is the contents of Israel's hope throughout its history. Any moment in history therefore could be conceived as the beginning of the last fulfilment, and so the prophets could always combine their words concerning the near future with their absolute promises of the completion of the word of the Lord. From the varying circumstances of the different ages they again and again received impulses for a richer and deeper conception of the age of fulfilment, but the core was always the same, and the expectations, that salvation was immediately imminent, were always, in all ages, equally living. So the contradiction between the human, historical element in prophecy, and the divine part of it, is dissolved. The proclamation of the immediate imminence of salvation is disproved by history and accordingly it cannot be directly derived from divine revalation. The divine plan was always far greater, than the prophets perceived, and many forms which they considered indispensable, had to be broken in order to let the new contents appear in full purity. But the expectation of the near fulfilment of the hopes nevertheless was an indirect fruit of Revelation, viz. of the striving, inherent in the Old Covenant itself, for a realization of the Ideal, given in it.

So fine the ideas of BuHL here briefly and imperfectly summarized may be, I think it obvious that his criticism against HofmanN, that the single, individual words of prophets - and also of other speakers in the Old Dispensation - do not get what they have a right to claim, can still be turned against himself. The use of the Old Testament in the New Covenant is not only a consideration of the long and dramatic history of Israel. The preacher, who chooses a concrete Old Testament text will of course have to place this text in the historical context to which it belongs inside Israel's religious history. But he will also - in this context - ask how to apply it to the needs of his hearers.

Here we first have to say something of the $A c t u$ ality of the texts. 
Luther, in a famous dictum on the value of the Psalms, tells us - what I think everybody who has tried to live with the texts in devotional reading, e.g. in the service of the Anglican Church, has experienced - that the Psalms can give us words to express our different moods, our doubts and temptations, our hopes and fears. The prayers become our own prayers. And this applies also to other texts. A man may have to face an operation to regain the use of his limbs, paralyzed by some pressure on important nerves by a dislocation in his backbone. Incidentally - for he has not discovered that his copy of the New Testament has an inclination to open just at that place! - he gets as his daily text the story in the begining of Acts 3, of Peter and John healing the paralyzed man sitting at the door of the temple, called the beautiful. Or he may have to go to some devotional meaning, where his service as a minister of the Church is necessary, and have to leave his wife and small children alone in a summer hut in some lonely place, with the rumours of an escaped murderer being at large in the neighbourhood disturbing his peace of mind. And to him come, strangely, the words to Israel in the context of the commandment to go up to the three annual festivals, not to fear that enemies will harrass their country during their absence, for God will protect their houses. In both cases he gets the quietness of mind necessary for him.

I call this "Actuality". Words of the Bible, belonging to definite historical situations, apply themselves to analogous situations in the daily life of men. And in the same way "History can repeat itself" in the greater life of the world. During the occupation of Denmark and I think of Holland and other countries, and I think in all the countries involved in the war, also in Germany - it often happened that a word of e.g. a prophet came to us and caused a smile, sure of final victory, to appear on the faces of readers or hearers. My colleague Hvidberg is editor of the "Church Page" of a great Copenhagen newspaper. And Sunday after Sunday he placed, under rubric "The Bible says...", some shorter or longer passage from the Bible, and mostly from the Old Testament, in one of his columns - for the edification and - what often is the same - for the amusement of his readers. The quotations were always extremely "actual". Once it was the satirical dirge on the fallen tyrant in Is. 14.

But we also know the complaint from Bible readers, that they do not "get anything" from their reading. And worse - we can feel quite out of contact, and even in opposition to the text before us. Here we generally mention the curses against the enemies in the Psalms. But also these paragraphs can have their "actuality". An enemy - the war taught me that - can identify himself so evidently with Evil, that it is duty to refrain from him and wish his downfall. And here also the actual cultic interpretation of the texts may be helpful, when we 
learn that the enemies in the psalms are primarily the powers opposing God and his Anointed in his fight to establish peace and blessing in the world: Then the hate towards enemies, expressed in the poems, is used by us to denounce the enemies of God, the opponents of salvation.

A still greater difficulty I have always found in texts, again when chanting Psalms in the Anglican service, texts which profess the innocence of the " $I$ " in the poem. It is very difficult to sing "I have kept Thy commandments". For I have not.

Here again the modern understanding of Psalms gives us help. When most Psalms originally belonged to the Royal ritual, destined for the sacral king, the present Saviour-Messiah, then a christological interpretation becomes legitimate. The present sacral Saviour-King of the Psalm is the "type" of the Christ present in his Church with the full fruit of his fight against the powers of Evil. He has taken my sins upon Himself, and he has given me his own justice and graciously made me as innocent as himself. That is the "fulfilment" of the Psalm. in the light of which we can sing it.

In such different ways texts of the Bible, also from the Old Testament, become "actual" in our life and in history. ${ }^{1}$ ) The last example shows how we must, in some cases, take refuge to a re-interpretation in the light of the "fulfilment" of the text in the New Covenant. In other cases it may be enough to realize that a text has already been re-interpreted in the Old Testament context. The story of Jacob wrestling with God (Gen. 32) I shall not try to interpret "christologically". I think it should be sufficient, as dr. BRODERSEN does'), to point out that the Yahwist who accepted the story in his work, must have applied some sort of re-interpretation to it already.

In some cases we may have recourse to "e $\mathrm{s} \mathrm{h}$ a tologiza$\mathrm{t} i$ o $\mathrm{n}^{\prime \prime}$ in this process of re-interpretation. Reading Ps. 46 with its picture of actual victory of God over his enemies, and his establishment of eternal peace on earth, we cannot but realize that this is not so. Here we experience what Israel experienced, when history taught that the conception of the cultic presence of God and his Anointed as guarantees of actual, present blessing, was not the whole truth. But this Psalm, and similar poems, were in a later age read as expression of hope for the coming of the kingdom of God. We may do the same. For as said above, the conception of the Church is that Christ is sacramentally present, but present as the coming Glory. That is the spirit in which Luther re-interpreted Ps. 46 in his "Ein feste Burg ..."

1) In the last volume of Haandbog i Kristendomskundskab, Dr. Broderser, Dr. Hauge, and $I$, have attempted to interpret Old Testament texts on these lines. 
I must cease giving examples. The last part of my article has become only a sketch, trying to give hints for reading the Bible. I only want to say now at last, that it has been my aim always to establish a narrow connection between the "scholarly" reading, so as it takes shape in modern research, and the devotional reading.

Aage Bentzen.

Copenhagen, 23rd March, 1950. 